\title{
The Challenges of Evolution and the Metaphysics of Creation
}

\author{
William E. Carroll ${ }^{1}$
}

For as long as human beings have reflected on nature and their place in nature, they have been fascinated with questions of origins: their own individual origins, the origins of their family, of the human race, the origin of life and, ultimately, of the universe itself. We move carelessly at times among different senses of what we mean by "origins," resulting in ambiguity and confusion. We can speak of origins in terms of cosmology, biology, philosophy, and theology, but, if we fail to keep distinct the different senses of "origin" and the different modes of analysis with respect to various disciplinary inquiries, our understanding is seriously compromised. To speak of the origin of life - or, perhaps better, the origins of life, we need to be attentive to recent developments in biology, especially evolutionary biology, and the relationship of these developments to broad themes in the philosophy of nature, metaphysics, and theology.

What are the challenges - alleged and real - that evolutionary biology presents to traditional notions of creation and of God as Creator? After the life and work of Charles Darwin "any thoughts we may have about God can hardly remain the same as before." Such, at least, is the observation of Professor John Haught of Georgetown University, and it is a view shared by many. As Haught notes, "Evolutionary science has changed our understanding of the world dramatically, and so any sense we may have of a God who creates and cares for this world must take into account what Darwin and his followers have told us about it" (Haught, 2000). Although evolutionary science has significantly changed our view of the world and of ourselves, I am not persuaded that our thoughts about God need to undergo a radical revision. Of course, it depends on the particular thoughts about God to which one is referring. "As long as we think of God," Haught writes, "only in terms of 'order' or 'design,' the 'atheism' of many evolutionists will seem appropriate." Rather than accept the conclusions of the "new atheism," associated with thinkers such as Richard Dawkins and Daniel Dennett, who connect atheism with Neo-Darwinian materialism, Haught and others urge a "new theism" consistent with the evolving universe disclosed by contemporary science.
More generally, the contention is that the novelty, dynamism, chance, and self-organizing principles which we find in nature are not consistent with an omnipotent, omniscient, and timeless God, especially as that God came to be described using categories of Aristotelian philosophy. Additional reasons offered for rejecting the traditional conception of God include the claim that Thomas Aquinas' famous distinction between God as Primary Cause and the whole array of secondary causes is incoherent and that the god of Aristotle and Aquinas is religiously objectionable since such an unchanging god is not the God of love, or a God who suffers for us, as depicted in the Bible.

A view more radical than Haught's proposal to find a new understanding of God in keeping with the insights of contemporary science is that of Steven Pinker. Pinker, professor of psychology at Harvard, is well-known for his recent book, The Better Angels of our Nature: Why Violence Has Declined. In an essay in the journal The New Republic, with the title, "Science is Not Your Enemy" (6 August 2013), he tells scholars working in the humanities that they should welcome the insights science offers for their disciplines. What is of special interest for us are his remarks about science and religion. Whereas Pinker thinks that humanists need not fear science, certainly those thinkers committed to broadly religious views of the world do have much to worry about if Pinker is right. As he says, "the moral worldview of any scientifically literate person - one who is not blinkered by fundamentalism, -- requires [my italics] a radical break from religious conceptions of meaning and value." He offers a litany of what "we know":

To begin with, the findings of science entail that the belief systems of all the world's traditional religions and cultures - their theories of the origins of life, humans, and societies - are factually mistaken. We know, but our ancestors did not, that humans belong to a single species of African primate that developed agriculture, government, and writing late in its history. We know that our species is a tiny twig of a genealogical tree that embraces all living things and that emerged from prebiotic chemicals almost four billion years ago.

Fecha de envío: 17de mayo de 2016 - Fecha de aceptación: 31 de mayo de 2016

(1) Faculty of Theology and Religion, University of Oxford

Autor de Correspondencia: william.carroll@bfriars.ox.ac.uk 
We know that out intuitions about space, time, matter, and causation are incommensurable with the nature of reality on scales that are very large and very small. We know that the laws governing the physical world (including accidents, disease, and other misfortunes) have no goals that pertain to human well-being. There is no such thing as fate, providence, karma, spells, curses, augury, divine retribution, or answered prayers - though the discrepancy between the laws of probability and the workings of cognition may explain why people believe there are. And we know that we did not always know these things, that the beloved convictions of every time and culture may be decisively falsified, doubtless including some we hold today.

If Pinker is correct, and if we are "scientifically literate," we must reject as false what traditional religions tell us about the origins of life and, in particular, of human life. It is not difficult to find any number of examples which suggest that one must choose between so-called traditional religious conceptions of God and divine agency, on the one hand, and the claims of evolutionary biology - as well as cosmology and the neurosciences - on the other hand.

On the contrary, I think that the challenges that evolutionary biology present to theology do not so much demand a "new theism," much less a return to some form of deism, or an outright embrace of atheism, as they offer us the opportunity to re-appropriate insights of Thomas Aquinas, especially concerning the doctrine of creation, God's transcendence, and God's action in the world. In a moment, I will say a little more about why there ought to be a renewed interest in the philosophy and theology of Thomas Aquinas in the context of developments in biology, but first, some general remarks.

Evolutionary biology surely challenges the conception that each of the various types of living things is the result of some special divine act, some kind of special creation, or that the order and design in nature must be the result of a type of divine manipulation with little or no reference to natural causes themselves. Too often creation had been seen as the bestowing of order and thus, if order could be explained by biological processes, it would seem that there was no need for a creator. The importance of God as designer and orderer had been emphasized by the physico-theologians (especially in England) in the seventeenth and eighteenth centuries; it was a view of God strongly criticized by David Hume. Indeed, various forms of modern atheism have their origins in the rejection of the God set forth by physico-theology.

In important ways, evolutionary biology has helped us to see the inadequacies of what had become generally accepted understandings of creation and of divine agency, but these apparently discredited understandings are not those of Thomas Aquinas. The god who, after Darwin, must be seen in new terms is not really the God described by Thomas. My point is that after Darwin's challenge we have new reasons for returning to the thought of Thomas Aquinas on these and related topics. We do not need to appeal, as many do, to a kenotic theology of creation, according to which God limits His power in order to allow for the vibrant causal agency in nature that evolution and the other sciences now describe. Nor must we embrace versions of process theology in which God and nature are evolving together. As we shall see, the autonomy and integrity of nature, so important for contemporary science, are part of Thomas' created universe: creation, for him, is the causing of existence, it ought not to be identified essentially as the ordering of reality. The path to God as Creator, that Darwin has helped to prepare by rejecting certain established views of god as the grand designer, can lead us back to Thomas' view of creation and science.

My over-arching concern is about the relationship between the traditional doctrine of creation and the claims made by and on behalf of contemporary science, in particular claims that have their roots in evolutionary biology. As will be evident, my analysis of creation and the natural sciences will also be relevant to claims made using various cosmological theories about the origin of the universe as well as claims about divine agency in a world described by relativity theory and quantum mechanics.

Contemporary science, and especially evolutionary biology, raise important questions as to how we understand nature and human nature, and, in some cases, God as well. Many of these questions are properly the subject of a philosophy of nature - that more general science of nature which examines the nature of change, time, the unity and identity of individual substances, the nature of life and how living things differ from the non-living. We might add to this list the vexed question of what it means to speak of a "species" and whether we can distinguish among the meanings of species in biology and philosophy. My focus in this essay, however, is on creation and the natural sciences, and, as my title indicates, I will discuss the "metaphysics of creation," since, as you will see, a central thesis I will defend is that creation is properly a subject in metaphysics and theology, not in the natural sciences. Indeed, I will emphasize the metaphysical understanding of creation, especially as that understanding was developed by Thomas Aquinas. We will have to keep in mind fundamental distinctions among the explanatory domains of the contemporary natural sciences, the philosophy of nature, metaphysics, and theology. A great deal of the confusion in discourse today about evolution and creation and about cosmology and creation, for that matter - is the result of the failure to keep these explanatory domains distinct, indeed, the failure to recognize that there are explanatory domains of reality beyond those of the natural sciences. 
As part of the justification for my emphasis on the importance of understanding the doctrine of creation in examining developments in contemporary biology about what living things are and how they have developed, I should like to call to your attention a new book by Michael Hanby, No God, No Science? Theology, Cosmology, and Biology. I mentioned his analysis in previous lectures, but for now, let me note a crucial thesis he defends. Hanby claims that "the doctrine of creation is essential to an understanding of the universe that is both comprehensive and nonreductive; and that the scientific and Darwinian revolutions, for all their stunning success in increasing our knowledge of the universe, have left us with a universe so reduced and fractured that it threatens to undermine the rationality and intelligibility of their own achievement." As a result of embracing an extrinsic notion of God as creator, that is, to think of God as a grand designer, the modern world "evacuates creatures of the unity, intelligibility, and interiority inherent in our elementary experience of them. This erases the difference heretofore distinguishing things 'existing by nature' from artifacts, as the objects of science are reimagined as sometimes highly organized aggregations of externally related parts" (Hanby, 2012). To see nature simply as the product of a divine craftsman is to reduce nature to an artifact and to find the intelligibility of nature exclusively in terms of "extrinsic relations" governing the interaction of parts. Only with a proper understanding of who the Creator is and what a creature is can one have an adequate understanding of living things precisely as living.

A return to the analysis of Thomas Aquinas would help to defuse much of the confusion in contemporary discourse about evolution, a discourse that can easily become obscured in broader political, social, and philosophical contexts. Evolution and creation have taken on cultural connotations, serve as ideological markers, with the result that each has come to stand for a competing world-view. For some, to embrace evolution is to affirm an exclusively secular and atheistic view of reality, and evolution is accordingly either welcomed or rejected on such grounds. Too often "creation" is confused with various forms of "creationism," which embrace either a literalistic reading of the Bible or think that creation must mean a kind of divine intervention in cosmic history with God's directly creating each individual species of living things.

The choice for many seems to be between an exclusively natural explanation of the origin and development of life: an explanation in terms of common descent, genetic mutations, and natural selection, on the one hand, and, on the other hand, an explanation that sees divine agency as the source of life in all its diversity and holds that human beings, created in the image and likeness of God, have a special place in the universe. The difference appears stark: either Darwin or God.
There are three features of evolutionary biology that seem to be of particular relevance to religious belief. The first is the claim of common ancestry: the view that all living things are historically and organically interconnected. Commentators describing the publication of a kind of rough draft of the total genetic constitution of the human species, its genome, were quick to point out that, since human genes look much like those of fruit flies, worms, and even plants, we have further confirmation of common descent from. To affirm a fundamental continuity among living things challenges the notion that distinct species were created by God through special interventions in nature. Common descent challenges as well the theological view that human beings, created in the image and likeness of God, represent an ontological discontinuity with the rest of nature. Specifically, it would seem that any notion of an immaterial human soul must be rejected if one is to accept the truths of contemporary biology.

More troublesome, so it seems, is the commitment to natural selection as the mechanism by which biological change has occurred. As a result of chance variations at the genetic level, variations in organisms result in some being better adapted to their environment and, then, nature "selects" these better adapted organisms and eliminates competitors. It is through this process of natural selection that evolutionary biology explains the way in which we can account for the diversity of species in the world. When proposed by Darwin, the radical nature of this claim was immediately obvious since it had been well-established that the emergence of new forms of life was the result of the action of a higher power in or above nature. Although there are debates among evolutionary theorists about the randomness and contingency at the basis of evolution, many biologists argue that at the very least biology itself does not reveal any fundamental order, purpose, or meaning in nature. For some, the randomness of evolutionary change is conclusive evidence that there is no purpose whatsoever in nature.

Francisco Ayala, a distinguished biologist and philosopher, commenting on the theological and philosophical implications of natural selection, writes:

"[l]t was Darwin's greatest achievement to show that the directive organization of living beings can be explained as the result of a natural process, natural selection, without any need to resort to a creator or other external agent.... Darwin's theory encountered opposition in religious circles, not so much because he proposed the evolutionary origin of living things (which had been proposed many times before, even by Christian theologians), but because his mechanism, natural selection, excluded God as accounting for the obvious design of organisms.... This is the conceptual revolution that Darwin completed - that everything in nature, including the 
origin of living organisms, can be explained by material processes governed by natural laws. This is nothing if not a fundamental vision that has forever changed how mankind perceives itself and its place in the universe."

Ayala emphasizes the radical nature of the Darwinian Revolution: it has, he says, "forever changed" how human beings understand themselves and their place in the universe. Many writers see a third feature of evolutionary biology which, for them, has crucial implications for religion: the pain, suffering, and waste in the world of living things - that evolutionary biology discloses -- and which is incompatible with any notion of an all-good and an all-powerful God. Although evidence from biology may bring the problem of evil in nature to our attention with a particular clarity, if not poignancy, it is not, however compelling it may be, an especially new argument against belief in a loving and providential God. Questions of evil in the world, whether it be the physical evil of pain and suffering, or the moral evil of sin, engaged the attention centuries ago of great thinkers such as Augustine and Aquinas.

Well before the time Darwin published On the Origin of Species (1859), the meaning of creation was often associated with the natural theology made famous by William Paley. Extrapolating from his famous example of finding a watch in the forest and concluding that there must be a watch-maker, Paley remarks: "every indication of contrivance, every manifestation of design, which existed in the watch, exists in the works of nature, with the difference, on the side of nature, of being greater and more, and that in a degree which exceeds all computation" (Paley \& Paxton, 1826). Such design is particularly evident in the anatomical features of living things, so that even more than the watch, the natural world exhibits "proof of design, and of a designing Creator" (Paley \& Paxton, 1826). The evidence of design is so overwhelming, that Paley can write of "the necessity of an intelligent Creator." Paley's excursion into natural theology occurs in the context of a widely accepted natural philosophy according to which nature is conceived in inert mechanistic terms and God's agency is viewed as a master craftsman or designer. It was easy to conflate a designer with a creator and to argue for God as creator from the evidence of design in the natural world - evidence that called for an external designer."The assumption that nature is possessed of vital powers or inherent forces sufficient to create its own order, or even to create life, was considered by William Paley to be tantamount to atheism" (Feser, 2013).

It was precisely such a notion of God as designer that Darwinian evolution has often been judged to call into question - or, at least, this was (and is) the fear of many who opposed the new theory.
The Darwinian challenge to natural theology was expressed by Darwin himself: "the old argument from design in nature, as given by Paley, which formerly seemed to me so conclusive, fails, now that the law of natural selection has been discovered" (Hodge \& Radick, 2003).

There is a lively scholarly debate concerning the reaction of Darwin, himself, to the tradition - or better, the traditions of natural theology - evident in $19^{\text {th }}$ Century Britain (Kohn, 1989). Some see Darwin as a "reformer of natural theology," emphasizing the regularity and intelligibility of the laws of nature as evidence for these laws' being created, rather than referring to the particular features and adaptiveness of natural phenomena, as Paley had. Another school of thought sees Darwin influenced by the naturalism - indeed, in some sense, a pantheistic ground of being- of thinkers like Alexander von Humboldt. Similarly, we need to recognize there was not a simple negative Christian reaction to Darwin. Some scholars like Aubrey Moore (1848-1890), who taught at Oxford, and Frederick Temple, later Archbishop of Canterbury, found that evolutionary biology offered an impetus for an expanded notion of God's action in the world - a God who is other than a master mechanic! Moore famously argued that under the guise of a foe, Darwin had done the work of a friend (Moore, 1889). It is not my purpose to explore the intricacies of how best to understand Darwin; rather, I am interested in looking at how the widely accepted view of Darwinian evolution as challenging the notion of creation opens up new possibilities for a more sophisticated understanding of creation (in the thought of Thomas Aquinas). We need to keep in mind, as well, that the very term "Darwinism" has many senses. It has taken on an "iconic meaning" and becomes part of a variety of scientific and philosophical theories - some of which are part of rival and incommensurable conceptual frameworks. At times, there has been what one scholar calls a "retrospective coronation" of certain features of Darwin's theory, and an incorporating within that theory of particular philosophical themes such as "chance," "contingency," "randomness," "mechanism," and "materialism." Often these features are not really what Darwin himself would endorse (Sloan, 2005). Again, I do not wish to offer an account of the vicissitudes associated with the various uses of "Darwinism" and "Neo-Darwinism." Here, I want only to emphasize a crucial phenomenon - the connection between the acceptance of Darwinian theory and the rejection of a particular view of creation (Depew, 2005). Although, as Michael Hanby has pointed out, despite the rejection of appeals to a grand designer or master craftsman, nature itself continued and continues to be seen in mechanistic terms. Responsibility for what has been produced may be transferred from God to "laws of nature," but nature itself remains obscured, as we lose the distinction between organisms and artifacts. 
If we identify God's creative act as essentially being the causing of order and design in nature, and hence view God as a kind of supernatural artisan or craftsman, we can see how evolutionary biology serves as a challenge to a god so conceived. Whereas some thinkers see the rejection of such a view of God as an opportunity to conceive of God in radically new terms, there is also an opportunity, I would suggest, to re-visit the traditional notion of God as Creator set forth by thinkers such as Thomas Aquinas. The designer god who has been replaced by natural processes is not the Creator Thomas describes. "After Darwin" we have the opportunity for a new appreciation of Thomas' analysis of creation. Why embrace this opportunity rather than follow some of the variants of a new theism? Well, the principal reason is that what Thomas says on the subject is true!

One final observation before we turn directly to Thomas Aquinas. One of the difficulties in taking seriously what Thomas has to say about creation and science - or about ethics, natural law, and metaphysics, for that matter - is that we face a grand meta-narrative of modernity, according to which the modern world, in particular the modern world of science, has its origins in an intellectual revolution in the $17^{\text {th }}$ Century which involved the rejection of Aristotelian science, and the philosophical insights associated with it. According to this narrative, modern science, in the figures of Galileo and Newton, for example, made scientific advances by rejecting the science inherited from antiquity and the Middle Ages. If we study Aristotle or Thomas at all, we look to their thought, especially on science, as fossils of an extinct species, worthy of archaeological interest at best. It is not my purpose here to offer a challenge to this narrative of modernity. Here I want to acknowledge its existence and ask that you put it aside, at least for a little while, to consider Thomas a worthy interlocutor for contemporary issues and not someone whose thought has somehow been made obsolete by the arrival of modernity.

After Darwin, we should no longer accept those notions of creation and divine agency which are incompatible with an evolving universe in which there is real novelty and in which the processes of development and the emergence of new species can be explained by principles in the universe. Thomas Aquinas remains an excellent guide for coming to terms with "God after Darwin." As Thomas would argue, the very processes which evolutionary biology explains depend upon God's creative act. The ultimate intelligibility of evolution itself depends upon a source which transcends the processes of nature. In fact, without creation understood as the very fact that all that is completely dependent upon God as cause, there would be no evolution at all. Furthermore, for Thomas, nature contains intrinsic principles of dynamic activity, an integrity which is not challenged by a robust notion of divine omnipotence, but is made possible by this omnipotence.

\section{Thomas Aquinas on Creation}

For the rest of my comments I want to describe briefly what Thomas says about creation (Baldner et al., 1997; Carroll \& Velásquez, 2002; Carroll, 2011). First, a quick linguistic point. Each time I use the word "creation"I mean the act by which causes things be, as distinct from the results of that act - for the results, I will speak of creatures or created effects.

Mediaeval discussions about creation (especially the intelligibility of creatio ex nihilo), divine agency, and the autonomy of nature, and ultimately the very possibility of the natural sciences' discovering real causes in nature, provide a rich source of insights for us today. What Avicenna, Maimonides, and Thomas Aquinas, for example, saw so clearly, that creation is an account of the existence of things, not of changes in and among things, allows us to conclude that there is no contradiction between creation, so understood, and any conclusion in the natural sciences.

The key to Thomas's analysis is the distinction he draws between creation and change, or, as he often remarked: creatio non est mutatio. In the Summa contra Gentiles (Book III, c. 18, 2), he observes: "creation is not a change, but the very dependency of the created act of being upon the principle from which it is produced. And thus creation is a kind of relation. ..." Creation, as a metaphysical and theological notion, affirms that all that is, in whatever way or ways it is, depends upon God as cause. The natural sciences, whether Aristotelian (with which Thomas was primarily concerned) or those of our own day, have as their subject the world of changing things: from the rippling gravitational waves in the early universe, to subatomic particles to acorns to galaxies. Whenever there is a change there must be something that changes. Whether the changes are biological or cosmological, without beginning or end, or temporally finite, they remain processes. Creation, on the other hand, is the radical causing of the whole existence of whatever exists. To cause completely something to exist is not to produce a change in something, is not to work on or with some existing material. If, in producing something new, an agent were to use something already existing, the agent would not be the complete cause of the new thing. But such complete causing is precisely what creation is. To create is to cause existence, and all things are totally dependent upon the Creator for the very fact that they are. As Thomas remarks in his treatise, De substantiis separatis [c. 9]: "Over and above the mode of becoming by which something comes to be through change or motion, there must be a mode of becoming or origin of things without any mutation or motion, through the influx of being." The expression "ex nihilo," or out-of-nothing, helps to capture the kind of causing which creation involves. God does not use anything at all - anything, that is, other than His own 
omnipotence, in the act of creating. God does not change "nothing" into "something." Rather, any thing separated from God as cause would be absolutely nothing at all.

God's creative act is the causing of existence, of the very being of all things that are and in whatever way or ways they are. To be created is to be completely dependent upon the Creator for all that one is. Such dependence in being is disclosed not in the natural sciences, but in metaphysics.

Thomas distinguishes between creation understood philosophically, in the discipline of metaphysics, and creation understood theologically. An important feature of this distinction with respect to our understanding of creation, is that, from a philosophical point of view, time is irrelevant to what it means to be created. The priority of Creator to creature is not a temporal order of before and after. Thus, for Thomas, an eternal created universe, that is a universe without a temporal beginning is completely intelligible. Thomas believes that the universe is not eternal, but he finds no reason to think that a created eternal universe is impossible. Thomas would have no difficulty accepting the intelligibility of contemporary cosmological theories which posit, for example, an eternal series of big bangs or an elaborate multiverse scenario according to which our universe is but one of an infinite number of universes. At least he would not think that these speculations, nor those in evolutionary biology, called into question the fact that whatever kind of universe there is, it still would be a created one.

Thomas shows us how to distinguish between the being or existence of creatures and the operations they perform. God causes creatures to exist in such a way that they are the real causes of their own operations.

For Thomas, God is at work in every operation of nature, but the autonomy of nature is not an indication of some reduction in God's power or activity; rather, it is an indication of His goodness. It is important to recognize that, for Thomas, divine causality and creaturely causality function at fundamentally different levels. In the Summa contra Gentiles (III, c. 70. 8), Thomas remarks that "the same effect is not attributed to a natural cause and to divine power in such a way that it is partly done by God, and partly by the natural agent; rather, it is wholly done by both, according to a different way, just as the same effect is wholly attributed to the instrument and also wholly to the principal agent." It is not the case of partial or co-causes with each contributing a separate element to produce the effect. God, as Creator, transcends the order of created causes in such a way that $\mathrm{He}$ is their enabling origin. For Thomas the differing metaphysical levels of primary and secondary causation require us to say that any created effect comes totally and immediately from God as the transcendent primary cause and totally and immediately from the creature as secondary cause (Shanley, 1998). In response to the objection that it is superfluous for effects to flow from natural causes since they could just as well be directly caused by God alone, Thomas writes that the existence of real causes in nature "is not the result of the inadequacy of divine power, but of the immensity of God's goodness."

For Thomas, creation is not primarily some distant event; rather, it is the on-going complete causing of the existence of all that is. At this very moment, were God not causing all that is to exist - from quantum processes to the color of the sky, to our own thoughts, hopes, and dreams - were God not to be causing everything that is, there would be nothing at all.

No matter how random one thinks evolutionary change is; no matter how much one thinks that natural selection is the master mechanism of change in the world of living things; the role of God as Creator, as continuing cause of the whole reality of all that is, is not challenged. We need to remember Thomas'fundamental point that creation is not a change, and thus there is no possibility of conflict between the explanatory domain of the natural sciences -- the world of change -- and that of creation. Evolutionary biology and all the natural sciences provide analyses of the changing world of physical reality, and offer explanations in terms of the causes and processes characteristic of physical things. Creation is an explanation of the ultimate origin of all things, including all things physical, and including their activities. The key words here are "ultimate origin". This kind of origin has nothing to do with a temporal beginning, nor with the origin and development of living things by natural processes; rather the doctrine of creation speaks to the on-going cause of existence itself-- without which there would be no physical things to study, nor anyone to study them.

\section{References}

Baldner SE, Carroll WE \& Studies PloM. (1997). Aquinas on Creation: Writings on the "Sentences" of Peter Lombard, Book 2, Distinction 1, Question 1. Pontifical Institute of Mediaeval Studies.

Carroll WE. (2011). Creation and Science: Has Science Eliminated God? Catholic Truth Society.

Carroll WE. (2016). The Challenges of Evolution and the Metaphysics of Creation. In Agora Lecture. Pontificia Universidad Católica de Chile. Carroll WE \& Velásquez O. (2002). La creación y las ciencias naturales: actualidad de Santo Tomás de Aquino. Ediciones Universidad Católica de Chile.

Darwin C. (1859). The Origin of Species. 


\section{Carroll et al.}

Depew D. (2005). Darwin's Multiple Ontologies. In Darwinism and Philosophy, ed. Hösle V \& Illies C, pp. 92-116. University of Notre Dame Press.

Feser E. (2013). Between Aristotle and William Paley: Aquinas's Fifth Way. Nova et Vetera 11, 740.

Hanby M. (2012). No God, No Science: Theology, Cosmology, Biology. John Wiley \& Sons, Incorporated.

Haught JF. (2000). God After Darwin: A Theology of Evolution. New York: Basic Books.

Hodge J \& Radick G. (2003). The Cambridge companion to Darwin. Cambridge, U.K. ; New York : Cambridge University Press, 2003.
Kohn D. (1989). Darwin's Ambiguity: The Secularization of Biological Meaning. The British Journal for the History of Science 22, 215-239.

Moore A. (1889). Science and Faith London.

Paley W \& Paxton J. (1826). Natural theology; or, Evidences of the existence and attributes of the Deity, illustr. by plates and notes by J. Paxton.

Shanley BJ. (1998). Divine Causation and Human Freedom in Aquinas. American Catholic Philosophical Quarterly 72, 100-108.

Sloan PR. (2005). It Might Be Called Reverence. In Darwinism and Philosophy, ed. Hösle V \& Illies C, pp. 143-165. University of Notre Dame Press. 